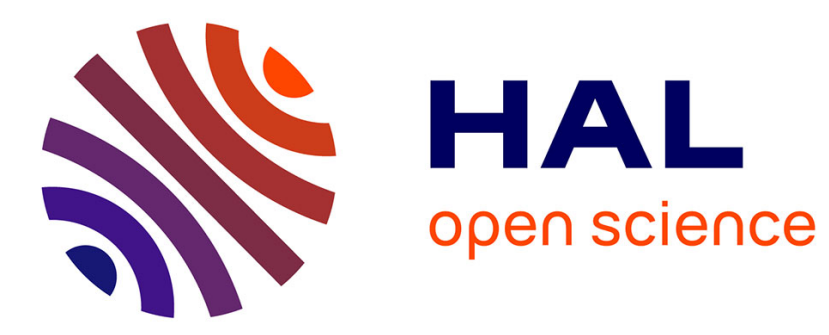

\title{
Systemic Risk Score: A Suggestion
}

Christophe Hurlin, Christophe Pérignon

\section{To cite this version:}

Christophe Hurlin, Christophe Pérignon. Systemic Risk Score: A Suggestion. 2013. halshs-00867063

\section{HAL Id: halshs-00867063 \\ https://shs.hal.science/halshs-00867063}

Preprint submitted on 27 Sep 2013

HAL is a multi-disciplinary open access archive for the deposit and dissemination of scientific research documents, whether they are published or not. The documents may come from teaching and research institutions in France or abroad, or from public or private research centers.
L'archive ouverte pluridisciplinaire HAL, est destinée au dépôt et à la diffusion de documents scientifiques de niveau recherche, publiés ou non, émanant des établissements d'enseignement et de recherche français ou étrangers, des laboratoires publics ou privés. 


\title{
Systemic Risk Score: A Suggestion
}

\author{
Christophe Hurlin ${ }^{1}$
}

\author{
Christophe Pérignon
}

First Draft: August 21, 2013

This Draft: September 27, 2013

\begin{abstract}
We identify a potential bias in the methodology disclosed in July 2013 by the Basel Committee on Banking Supervision (BCBS) for identifying systemically important financial banks. Contrary to the original objective, the relative importance of the five categories of risk importance (size, crossjurisdictional activity, interconnectedness, substitutability/financial institution infrastructure, and complexity) may not be equal and the resulting systemic risk scores are mechanically dominated by the most volatile categories. In practice, this bias proved to be serious enough that the substitutability category had to be capped by the BCBS. We show that the bias can be removed by simply standardizing each input prior to computing the systemic risk scores.
\end{abstract}

\section{Introduction}

The supervision of globally systemically important financial institutions (G-SIFIs) is a major pillar, along with leverage and liquidity ratios and countercyclical buffers, of the post-crisis banking regulation. As of 2016, the financial institutions that contribute the most to the risk of the financial system will be subject to more intense supervision and have to maintain higher regulatory capital. According to the latest draft released by the Basel Committee on Banking Supervision (BCBS, 2013), the additional capital

\footnotetext{
${ }^{1}$ Hurlin is professor of econometrics at the University of Orléans, France, and Pérignon is associate professor of finance at HEC Paris, France. Emails: christophe.hurlin@univ-orleans.fr; perignon@hec.fr. Without implicating them in positions taken here, we would like to thank for their comments on earlier drafts, Sylvain Benoit, Christian Gourieroux, Jean-Cyprien Héam, David Thesmar, and Jean-Paul Renne.
} 
requirement will range between 1 and $3.5 \%$ of risk-weighted assets, depending on the bank's scores of systemic importance. ${ }^{2}$ According to Fitch (2012), the 29 G-SIFIs would need to raise $\$ 566$ billion in extra capital, which represents a $23 \%$ increase relative to the banks' aggregate regulatory capital (see Appendix 1 for the latest list of G-SIFIs).

The scoring methodology developed by the BCBS is both simple and intuitive. It aggregates information about five broad categories of systemic importance: size, cross-jurisdictional activity, interconnectedness, substitutability/financial institution infrastructure, and complexity. ${ }^{3}$ In order not to favor any particular facet of systemic risk, the BCBS aims to give an equal weight to each input (see BCBS, 2013, page 5):

"The methodology gives an equal weight of $20 \%$ to each of the five categories of systemic importance".

To meet this objective, the original data are transformed as follows (page 6):

"For each bank, the score for a particular indicator is calculated by dividing the individual bank amount (expressed in EUR) by the aggregate amount for the indicator summed across all banks in the sample. This amount is then multiplied by 10,000 to express the indicator score in terms of basis points.

For example, if a bank's size divided by the total size of all banks in the sample is 0.03 (ie the bank makes up 3\% of the sample total) its score will be expressed as 300 basis points. Each category score for each bank is determined by taking a simple average of the indicator scores in that category. The overall score for each bank is then calculated by taking a simple average of its five category scores. The maximum total score, ie the score that a bank would have if it were the only bank in sample, is 10,000 basis points (ie 100\%)."

\footnotetext{
${ }^{2}$ Based on their systemic risk score, banks are allocated into buckets. There are four populated equally sized buckets (1 to 4), with an additional empty bucket (5) with a higher loss absorbency requirement of $3.5 \%$ of riskweighted assets to provide an incentive against banks further increasing their systemic importance. Any bank with a score lower than the cutoff level of the first bucket is classified as non-systemically important and faces no additional capital charge.

${ }^{3}$ As shown in the Appendix 2, most categories are then divided into two or three sub-categories.
} 
We show in this note that the relative importance of the five categories may not be equal and that the resulting systemic risk score will be mechanically dominated by the most volatile categories. As a result, the scores, the ranking of banks, and in turn, their extra capital buffer, will be driven by a subset of variables only, i.e., the most volatile ones, which seems inconsistent with the original intention of the BCBS to give equal weight to each input.

The documented bias is likely to have severe implications in practice. Indeed, the BCBS acknowledges that some variables have an abnormally high influence on the value of the systemic risk score. On page 6, the Committee states that:

"The Committee has analysed the application of the scoring methodology described above to three years of data supplied by banks. It has found that, relative to the other categories that make up the G-SIB framework, the substitutability category has a greater impact on the assessment of systemic importance than the Committee intended for banks that are dominant in the provision of payment, underwriting and asset custody services. Therefore, the Committee has decided to apply a cap to the substitutability category score."

The truncation of some inputs is a crude and had hoc way of reducing the influence of the most volatile variables. Instead, we suggest a slightly modified formula that prevents any category to play a dominant role in the computation of the score. The adjustment we suggest is to scale it by its cross-sectional standard deviation prior to the calculation of the score. This simple modification guarantees that each input contributes equally to the systemic risk score.

The rest of this note is structured as follows. We explain and document the bias in Section 2 and suggest a way to correct it in Section 3. We summarize and conclude this note in Section 4. 


\section{Why the Systemic Risk Scores can be Biased?}

Each bank $i$, for $i=1, \ldots, N$, is characterized by $K$ inputs or categories denoted $X_{i 1}, \ldots, X_{i K}$. The systemic risk score for bank $i$, denoted $S_{i}$, is then defined as a weighted sum of these $K$ inputs:

$$
S_{i}=\sum_{j=1}^{K} w_{j} \times x_{i j}
$$

where $w_{j}$ corresponds to the weight (common to all banks) of input $j$ in the systemic risk score, and $X_{i j}=X_{i j} / \sum_{i=1}^{N} X_{i j} \times 100$ corresponds to the relative value (in percentage) of input $j$ for bank $i$. Note that all $x_{i j}$, for $j=1, \ldots, K$, have the same empirical mean.

Currently, the BCBS considers $K=5$ inputs, namely the bank's size, cross-jurisdictional activity, interconnectedness, substitutability/financial institution infrastructure, and complexity. In order to give the same importance to each of these categories, the Committee considers an equally weighted index with $w_{j}=1 / K$. This assumption is justified by the fact that all inputs have the same importance in the score: an increase of $10 \%$ of a given input can be offset by a decrease of $10 \%$ of another input.

However, this assumption becomes problematic when the cross-sectional variances of the inputs are different. In such a case, a $10 \%$ increase of a given input does not represent the same signal if the factor has a variance of 1 or a variance of 100 . One implication of this situation is that the ranking issued from the systemic risk score will be mainly driven by the most volatile categories. ${ }^{4}$

To illustrate this point, let us assume that the $K$ inputs are independently distributed with a common mean but have different cross-sectional variances. For simplicity, we assume that the inputs are generated by:

$$
X_{i j}=\beta+a_{j} u_{i}
$$

\footnotetext{
${ }^{4}$ For an in-depth discussion of score aggregation techniques in finance, see for instance Gagliardini, Gourieroux and Rubin (2013).
} 
where $\beta>0, u_{i}$ is an i.i.d. uniform variable on $[-1,1]$ and $a_{j}=10 \times j$. Note that by definition, $\operatorname{var}\left(u_{i}\right)=1 / 3$. In this simple example, the $K$ inputs have a mean equal to $\beta$ but $\operatorname{var}\left(X_{K}\right)>\ldots>\operatorname{var}\left(X_{1}\right)$ since $\operatorname{var}\left(X_{j}\right)=$ $(100 / 3) \times j^{2}$. By simulation, we generate a series of realizations for $X_{i j}, x_{i j}$, and $S_{i}$, and then compare (1) the firms' ranking based on the equally weighted systemic risk score to (2) the firms' ranking based on each of the $K$ inputs. In accordance with BCBS (2013), we use $K=5$ inputs and $N=75$ banks. $^{5}$

Figure 1 displays the average rank correlations (Spearman) measured between the ranking based on $S_{i}$ and the input $j$. The average rank correlations are based on 1,000 simulations. We can verify that the correlation increases with the variance of the input: the higher the volatility of the input, the more similar are the rankings based on the score and the input. ${ }^{6}$ The fact that the systemic risk scores are distorted by the most volatile inputs comes in violation of the Committee's intention to give all inputs equal weights. The high sensitivity of the scores with respect to volatility seems to be an unintended consequence of the current methodology.

Figure 1: Correlation between Score-based Rankings and Input-based Rankings

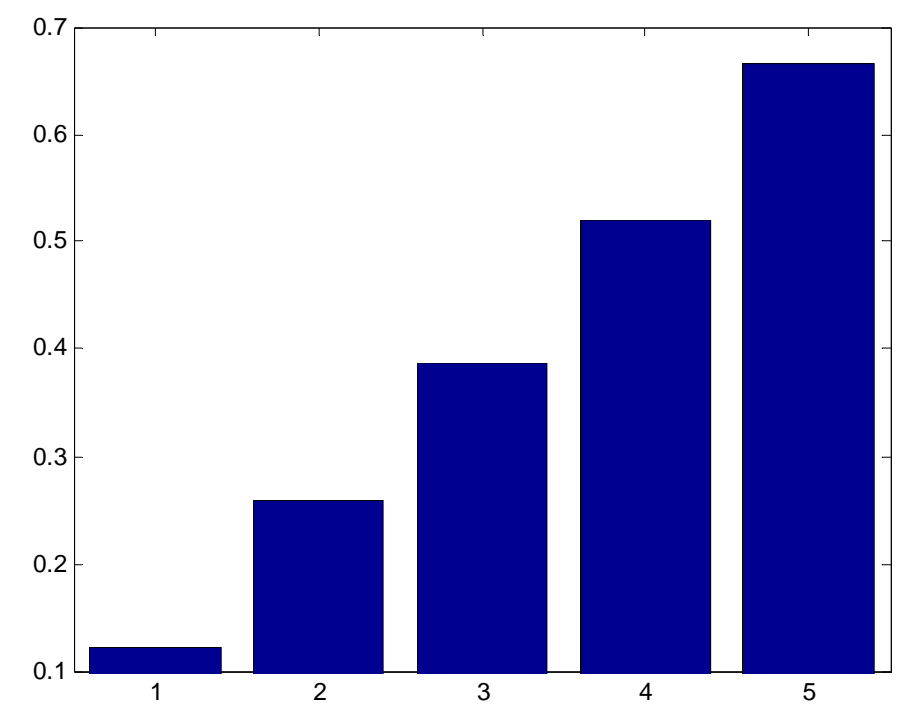

\footnotetext{
${ }^{5}$ The sample comprises the 75 largest global banks based on their total exposures as defined for use in the Basel III leverage ratio (BCBS, 2013).

${ }^{6}$ We obtain similar results when we allow the $K$ inputs to have different means $\left(\beta_{j}\right)$.
} 


\section{A Potential Correction}

We show in this section how to remove the above-mentioned bias. One simple correction consists in standardizing the variables that enter in the definition of the index by their volatility. In that case, the systemic risk score becomes:

$$
\tilde{S}_{i}=\sum_{j=1}^{K} w_{j} \times \frac{x_{i j}}{\sigma_{j}}
$$

where $\sigma_{j}^{2}=\operatorname{var}\left(x_{i j}\right)$ corresponds to the cross-sectional variance of input $j$. Note that the rest of the formula remains unchanged. In particular the weight of each input is still equal to $w_{j}=1 / \mathrm{K}$. Figure 2 displays the corresponding average rank correlations (obtained for 1,000 simulations) between the rankings based on the modified score $\tilde{S}_{i}$ and the initial inputs $X_{j}$. The suggested correction guarantees that each input contributes equally to the systemic risk score as desired by the BCBS.

Figure 2: Correlation between Modified Score-based Rankings and Input-based Rankings

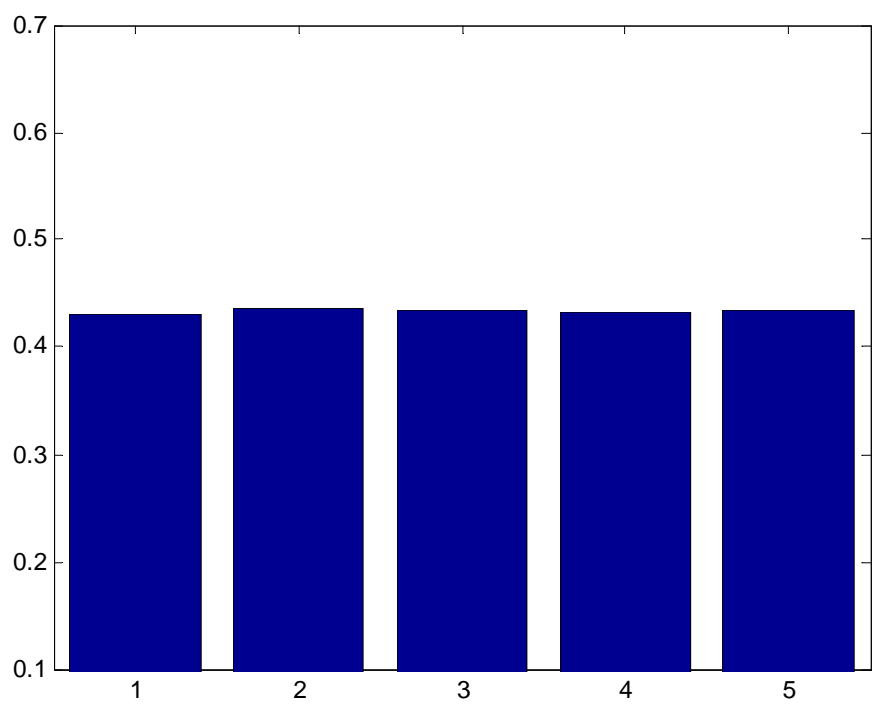




\section{Conclusion}

The purpose of this note is twofold. First, it aims to show that the methodology for computing systemic risk scores proposed by the BCBS (2013) can be biased towards the most volatile categories. Second, it suggests a simple modification of the current methodology that corrects for this bias.

The slightly modified formula proposed in this note is as simple as the one currently advocated by the Committee, but it is robust to the presence of highly volatile variables and it always guarantees that all categories contribute equally to the systemic risk score.

\section{References:}

[1] Basel Committee on Banking Supervision (2013) Global systemically important banks: updated assessment methodology and the higher loss absorbency requirement, July 2013, Bank for International Settlements.

[2] Financial Stability Board (2012) Update of group of global systemically important banks.

[3] Fitch (2012) Basel III: Return and deleveraging pressures, May 17.

[4] Gagliardini P., C. Gourieroux and M. Rubin (2013) Positional Portfolio Management, Working Paper, Swiss Finance Institute. 
Appendix 1: List of Globally Systemically Important Banks (November 2012)

\begin{tabular}{|c|c|}
\hline Bucket & G-SIBs in alphabetical order within each bucket \\
\hline $\begin{array}{c}5 \\
(3.5 \%)\end{array}$ & (Empty) \\
\hline $\begin{array}{c}4 \\
(2.5 \%)\end{array}$ & $\begin{array}{l}\text { Citigroup } \\
\text { Deutsche Bank } \\
\text { HSBC } \\
\text { JP Morgan Chase }\end{array}$ \\
\hline $\begin{array}{c}3 \\
(2.0 \%)\end{array}$ & $\begin{array}{l}\text { Barclays } \\
\text { BNP Paribas }\end{array}$ \\
\hline $\begin{array}{c}2 \\
(1.5 \%)\end{array}$ & $\begin{array}{l}\text { Bank of America } \\
\text { Bank of New York Mellon } \\
\text { Credit Suisse } \\
\text { Goldman Sachs } \\
\text { Mitsubishi UFJ FG } \\
\text { Morgan Stanley } \\
\text { Royal Bank of Scotland } \\
\text { UBS } \\
\end{array}$ \\
\hline $\begin{array}{c}1 \\
(1.0 \%)\end{array}$ & $\begin{array}{l}\text { Bank of China } \\
\text { BBVA } \\
\text { Groupe BPCE } \\
\text { Group Crédit Agricole } \\
\text { ING Bank } \\
\text { Mizuho FG } \\
\text { Nordea } \\
\text { Santander } \\
\text { Société Générale } \\
\text { Standard Chartered } \\
\text { State Street } \\
\text { Sumitomo Mitsui FG } \\
\text { Unicredit Group } \\
\text { Wells Fargo }\end{array}$ \\
\hline
\end{tabular}

Source: Financial Stability Board (2012). 
Appendix 2: Indicators and weights used in the Systemic Risk Score (BCBS, 2013)

\begin{tabular}{|c|c|c|}
\hline Category (and weighting) & Individual indicator & Indicator weighting \\
\hline \multirow[t]{2}{*}{ Cross-jurisdictional activity (20\%) } & Cross-jurisclictional claims & $10 \%$ \\
\hline & Cross-jurisdictional liabilities & $10 \%$ \\
\hline Size (20\%) & $\begin{array}{l}\text { Total exposures as defined for use in the Basel II } \\
\text { leverage ratio }\end{array}$ & $20 \%$ \\
\hline \multirow[t]{3}{*}{ Interconnectedness (20\%) } & Intra-financial system assets & $6.67 \%$ \\
\hline & Intra-financial system liabilities & $6.67 \%$ \\
\hline & Securities outstanding & $6.67 \%$ \\
\hline \multirow{3}{*}{$\begin{array}{l}\text { Substiturability/financial } \\
\text { institution infrastructure (20\%) }\end{array}$} & Assets under custody & $6.67 \%$ \\
\hline & Payments activity & $6.67 \%$ \\
\hline & $\begin{array}{l}\text { Underwritten transactions in debt and equity } \\
\text { markets }\end{array}$ & $6.67 \%$ \\
\hline \multirow[t]{3}{*}{ Complexity (20\%) } & $\begin{array}{l}\text { Notional amount of over-the-counter (OTC) } \\
\text { derivatives }\end{array}$ & $6.67 \%$ \\
\hline & Level 3 assets & $6.67 \%$ \\
\hline & Trading and available-for-sale securities & $6.67 \%$ \\
\hline
\end{tabular}

Source: Basel Committee on Banking Supervision (2013). 